\title{
TRADUÇÃO
}

\section{Excertos do livro de James Mill "Éléments d'économie politique"}

\author{
Karl Marx
}

Na compensação do dinheiro e do valor em metal, como na apresentação dos custos de produção como o único momento na determinação do valor, Mill comete - assim como a escola de Ricardo em geral - o erro de enunciar a lei abstrata sem a mudança ou sem a constante suspensão (Aufhebung) dessa lei - unicamente por meio da qual ela vem a ser. Se é uma lei constante que, por exemplo, os custos de produção em última instância - ou, antes, na coincidência de demanda e oferta que se cumpre de forma esporádica, contingente ${ }^{1}$ - determinam o preço (valor) ${ }^{2}$, então é igualmente uma lei constante que essa relação não coincida, isto é, que o valor e os custos de produção não estejam em nenhuma relação necessária. De fato, demanda e oferta coincidem tão-somente de maneira momentânea através das oscilações precedentes de demanda e oferta, através da desproporção entre custos de produção e valor de troca, assim como essa oscilação e essa desproporção se seguem novamente à coincidência momentânea. Esse movimento efetivo, do qual aquela lei é apenas um momento abstrato, ocasional e unilateral, a mais recente Economia Política o torna um acidente, algo não essencial. Por quê? Porque nas fórmulas exatas e precisas às quais a Economia Política a reduz, a fórmula fundamental, caso eles queiram enunciar aquele movimento abstratamente, deveria ser: a lei, na Economia Política, é determinada pelo seu contrário, a ausência de lei. A verdadeira lei da Economia Política é o acaso, de cujo movimento nós, os científicos, fixamos arbitrariamente alguns momentos na forma de leis.

A essência da coisa é alcançada, e muito bem, em um conceito quando Mill designa o dinheiro como o mediador da troca. A essência do dinheiro não consiste, em primeiro lugar, em que nele a propriedade é alienada, ${ }^{3}$ mas em que o movimento ou a atividade de mediação, o ato humano, social, mediante o qual os produtos dos homens se complementam mutuamente, é alienado* e se torna a característica de uma coisa material exterior ao homem, o dinheiro. Na medida em que o homem

\footnotetext{
1 No manuscrito, "contingente" encontra-se acima de "esporádica". (N.E.A. - Nota do editor alemão). 2 No manuscrito, "(valor)" encontra-se acima de "preço". (N.E.A.).

3 Onde o verbo "alienar" e seus adjetivos e substantivos derivados forem seguidos de um asterisco ("trabalho alienado"), trata-se, no original, do alemão entfremden; na ausência do asterisco, de entäußern. (N.T. - Nota do tradutor.).
} 
aliena essa atividade de mediação mesma, ele só é aqui ativo enquanto homem que se extraviou, como homem desumanizado; a relação mesma das coisas, a operação humana com elas, se torna operação de uma entidade exterior ao homem e acima do homem. Através desse mediador estranho - em vez de o próprio homem dever ser o mediador para os homens - o homem contempla sua vontade, sua atividade, sua relação com outros como poder independente dele e dos outros. Sua escravidão atinge, assim, o cume. Ora, que esse mediador se torne o deus real é algo claro, pois o mediador é o poder real sobre aquilo com que ele me medeia. Seu culto se torna fim em si mesmo. Os objetos, separados desse mediador, perderam seu valor. Portanto, apenas na medida em que o representam é que eles têm valor, enquanto originalmente parecia que ele só tinha valor na medida em que ele os representava. Essa inversão da relação originária é necessária. Esse mediador é, portanto, a essência extraviada de si mesma, alienada*, da propriedade privada, a propriedade privada que se tornou exterior a si mesma, alienada, assim como a mediação alienada da produção humana com a produção humana é a atividade genérica alienada do homem. Todas as propriedades que the cabem na produção dessa atividade se transferem, por isso, a esse mediador. 0 homem se torna, então, mais pobre enquanto homem, isto é, separado deste mediador, tanto quanto esse mediador se torna mais rico.

Cristo representa originalmente 1) os homens perante Deus; 2) Deus para os homens; 3 ) os homens ao homem.

Assim, o dinheiro representa originalmente, segundo seu conceito: 1) a propriedade privada para a propriedade privada; 2 ) a sociedade para a propriedade privada; 3 ) a propriedade privada para a sociedade.

Mas Cristo é o Deus alienado e o homem alienado. Deus só tem mais valor na medida em que representa Cristo, e o homem só tem mais valor na medida em que representa Cristo. Do mesmo modo com o dinheiro.

Por que a propriedade privada precisa passar para a essência do dinheiro [Geldwesen]? Porque o homem, como um ser sociável, precisa passar à troca, e porque a troca - sob o pressuposto da propriedade privada - precisa passar ao valor. É que o movimento mediador do homem que realiza a troca não é um movimento social, não é um movimento humano, não é uma relação humana, é a relação abstrata da propriedade privada com a propriedade privada, e essa relação abstrata é o valor, cuja existência real como valor é primeiramente o dinheiro. Uma vez que os homens que trocam não se comportam como homens uns para com os outros, a coisa perde então o significado de propriedade humana, de propriedade pessoal. A relação social de propriedade privada com propriedade privada é já uma relação na qual a propriedade privada é alienada* de si mesma. A existência para si dessa relação, o dinheiro, é portanto a alienação da propriedade privada, a abstração de 
sua natureza específica, pessoal.

A oposição da moderna Economia Política ao sistema monetário, système monétaire, não pode, portanto, apesar de toda sua perspicácia, levar a nenhum triunfo decisivo; pois, se a crua superstição político-econômica do povo e dos governos se atém ao saco de dinheiro sensível, tangível, evidente, e por isso acredita no valor absoluto dos metais nobres assim como em sua posse como a única realidade da riqueza, - se então o economista político esclarecido, conhecedor do mundo, vem e lhes demonstra que o dinheiro é uma mercadoria como qualquer outra, cujo valor, portanto, como de qualquer outra mercadoria, depende da relação dos custos de produção com a demanda, concorrência ${ }^{4}$ e oferta, com a quantidade ou concorrência das outras mercadorias, - então se replicaria corretamente a esse economista político que, todavia, o valor real da coisa é o seu valor de troca, e este existe, em última instância, em dinheiro, assim como este existe nos metais nobres, e que, portanto, o dinheiro é o verdadeiro valor das coisas e por isso é a coisa mais desejável. As doutrinas do economista político vão parar, em última instância, nessa sabedoria, só que ele possui a capacidade de abstração para distinguir essa existência do dinheiro sob todas as formas de mercadoria e assim para não crer no valor exclusivo de sua existência metálica oficial. - A existência metálica do dinheiro é apenas a expressão oficial óbvia da alma do dinheiro que se esconde em todos os membros das produções e movimentos da sociedade civil-burguesa [bürgerliche Gesellschaft].

A oposição dos economistas políticos modernos ao sistema monetário consiste apenas no fato de que eles apreenderam a essência do dinheiro em sua abstração e generalidade e, portanto, estão esclarecidos sobre a superstição sensível que acredita na existência exclusiva dessa essência no metal nobre. No lugar dessa superstição bruta, eles põem a superstição refinada. Uma vez que ambas, no entanto, possuem em essência uma raiz, então a forma esclarecida da superstição não leva a que se reprima totalmente a sua forma sensível bruta, porque ela não ataca a sua essência, mas apenas a forma determinada dessa essência. - A existência pessoal do dinheiro enquanto dinheiro - e não apenas como a relação interna, em si e oculta das mercadorias em sua conversação ou a relação hierárquica de umas para com as outras - essa existência corresponde tanto mais à essência do dinheiro quanto mais abstrata ela é, quanto menos natural é a relação que ela tem com as outras mercadorias, quanto mais ela aparece como produto e, todavia, novamente como não-produto do homem, quanto menos natural-espontâneo é seu elemento de existência, quanto mais produzida ela é pelo homem, ou, dito em termos da Economia Política, quanto maior é a proporção inversa de seu valor como dinheiro com o valor de troca ou o valor monetário do material no qual ela existe. Por isso, o dinheiro em papel e o número dos representantes de papel do dinheiro (como a letra de câmbio,

4 No manuscrito, "concorrência" encontra-se acima de "demanda". (N.E.A.). 
os mandatos, as notas promissórias) são a mais completa existência do dinheiro enquanto dinheiro e um momento necessário no progresso do desenvolvimento do dinheiro. No crédito, cuja expressão mais completa é o banco, ele adquire uma aparência, como se o poder daquela força alheia e material tivesse se rompido, a relação de autoalienação* tivesse sido suprimida [aufgehoben] e o homem estivesse novamente em relações humanas com o homem. Os Saint-Simonistas, iludidos por essa aparência, consideram o desenvolvimento do dinheiro, do título de crédito, do dinheiro de papel, dos representantes de papel do dinheiro, do crédito, do banco como uma supressão [Aufhebung] gradual da separação entre homem e coisa, entre capital e trabalho, entre propriedade privada e dinheiro e entre dinheiro e homem, a separação entre homem e homem. O banco organizado é, portanto, seu ideal. Mas essa supressão [Aufhebung] da alienação*, esse regresso do homem a si mesmo e, assim, ao outro homem, é apenas uma aparência; ela é uma autoalienação*, uma desumanização, tão mais infame e extrema na medida em que seu elemento não é mais a mercadoria, o metal, o papel, mas a existência moral, a existência sociável, o interior do próprio seio humano; na medida em que, sob a aparência da confiança do homem no homem, ela é a mais alta desconfiança e a completa alienação*. 0 que constitui a essência do crédito? Abstraímos aqui completamente do conteúdo do crédito, que é novamente o dinheiro. Abstraímos, então, do conteúdo dessa confiança, segundo o qual um homem reconhece o outro ao the antecipar valores e - no melhor dos casos, a saber, quando ele não é pago pelo crédito, ou seja, não é um usurário - oferece a seu próximo a confiança de que ele não é um trapaceiro, mas sim um homem "bom". Por homem "bom", o confiante entende aqui, como Shylock, um homem "pagador". - O crédito é pensável sob duas relações e sob duas distintas condições. As duas relações são: primeiro, um rico concede crédito a um pobre que ele toma por alguém diligente e decente. Essa espécie de crédito pertence à parte romântica e sentimental da Economia Política, a seus extravios, excessos, exceções, não à regra. Pressuposta apenas essa exceção, admitida essa possibilidade romântica, então a vida do pobre e seu talento enquanto uma atividade contam para o rico como uma garantia da restituição do dinheiro emprestado; ou seja, todas as virtudes sociais do pobre, o conteúdo de sua atividade vital, sua própria existência, representam para o rico o reembolso de seu capital com os juros de costume. A morte do pobre é, então, para o credor, o pior dos casos. Ela é a morte de seu capital mais os juros. Tenha-se em conta quanta vileza há na avaliação de um homem em dinheiro, como ocorre na relação de crédito. É óbvio que o credor, além da garantia moral, tem também a garantia da coação jurídica e ainda garantias mais ou menos reais por seu homem. Se aquele a quem o crédito é concedido é ele próprio alguém de posses, o crédito se torna apenas um mediador facilitador da troca, isto é, é o próprio dinheiro elevado a uma forma completamente ideal. 0 crédito é o juízo econômico sobre a 
moralidade de um homem. No crédito, o próprio homem se tornou o mediador da troca no lugar do metal ou do papel, não como homem, mas sim como a existência de um capital e dos juros. Portanto, o medium da troca, com efeito, retorna e é retransferido de sua figura material para o homem, mas apenas porque o homem mesmo, trazido para fora de si mesmo, se tornou em si mesmo uma figura material. Não é o dinheiro que está suprimido [aufgehoben] no homem - no interior da relação de crédito -, mas é o homem mesmo que se transformou em dinheiro, ou o dinheiro que nele se incorporou. A individualidade humana, a moral humana se transformou ela mesma tanto em um artigo de comércio quanto no material no qual o dinheiro existe. No lugar do dinheiro, do papel, é minha própria existência pessoal, minha carne e meu sangue, meu prestígio e virtude sociável que se tornaram a matéria, o corpo do espírito do dinheiro. o crédito não mais destrincha o valor do dinheiro em dinheiro, mas em carne e coração humanos. De tal modo, todos os progressos e inconsequências no interior de um sistema falso são o mais elevado retrocesso e a mais elevada consequência da vileza. - No interior do sistema de crédito, a sua natureza alienada* do homem opera, sob a aparência do mais elevado reconhecimento político-econômico do homem, de um modo duplo: 1. A oposição entre capitalista e trabalhador e entre grande e pequeno capitalista se torna ainda maior na medida em que o crédito só é concedido a quem já o tem e é uma nova oportunidade de acumulação para o rico, ou na medida em que o pobre vê toda a sua existência confirmada ou negada no juízo ou arbítrio casual do rico sobre ele, completamente dependente deste acaso; 2 . na medida em que a representação, a dissimulação e a hipocrisia mútuas são levadas ao extremo de que, além do juízo simples sobre aquele que não goza de crédito de que ele é pobre, advém ainda o juízo desmoralizador de que ele não possui nenhuma confiança, nenhum reconhecimento, e é portanto um pária social, um homem ruim; e na medida em que o pobre recebe adicionalmente à sua privação essa humilhação e a necessidade do humilhante pedido por crédito ao rico; 3. na medida em que por meio dessa existência completamente ideal do dinheiro a falsificação de moedas do homem não pode ser realizada em nenhuma outra matéria senão apenas em sua própria pessoa, ele próprio precisa fazer de si uma moeda falsa, obter crédito através de alguma malícia ou da mentira etc., e essa relação de crédito - tanto pelo lado do que oferece a confiança quanto pelo do que dela necessita - se torna objeto de comércio, objeto da fraude e do abuso mútuo. Aqui se mostra então, ainda de modo reluzente, a desconfiança como a base dessa confiança econômica; a ponderação desconfiada se o crédito deve ser ofertado ou não; a espionagem sobre os segredos da vida privada etc. do que busca o crédito; a revelação de insuficiências momentâneas a fim de derrubar um rival por meio de um abalo repentino de seu crédito etc. Todo o sistema da bancarrota, das empresas de fachada etc.... No crédito estatal o Estado tem a mesma posição que acima o 
homem... No jogo com os papéis estatais se mostra como ele se tornou um brinquedo dos homens de negócio etc.

4. O sistema de crédito encontra por fim sua forma perfeita no banco. A criação dos banqueiros, a dominação estatal do banco, a concentração do patrimônio nessas mãos, esse areópago econômico da nação, é a forma perfeita e acabada digna do dinheiro. Na medida em que, no sistema de crédito, o reconhecimento moral de um homem, assim como a confiança no Estado etc., adquire a forma do crédito, o segredo que há na mentira do reconhecimento moral, a vileza imoral dessa moralidade assim como a hipocrisia e o egoísmo naquela confiança no Estado, vem a primeiro plano e se mostra como aquilo que ele realmente é.

A troca tanto da atividade humana no interior da própria produção quanto dos produtos humanos uns pelos outros é = à atividade genérica e à fruição genérica, ${ }^{5} \mathrm{cuja}$ existência efetiva, consciente e verdadeira é a atividade social e a fruição social. $\mathrm{Na}$ medida em que a essência humana é a verdadeira comunidade dos homens, os homens criam, produzem, pela operação atualizadora de sua essência, a comunidade humana, ${ }^{6}$ o ser social, que não é um poder abstrato-universal em face do indivíduo particular, mas o ser de cada indivíduo, sua atividade própria, sua vida própria, seu espírito próprio, sua riqueza própria. Não é pela reflexão que surge, portanto, aquela verdadeira comunidade, ela aparece, então, pela necessidade e pelo egoísmo dos indivíduos, isto é, produzida de modo imediato pela operação de sua existência mesma. Não depende do homem que essa comunidade exista ou não; mas enquanto o homem não tiver se reconhecido (erkennt) como homem e organizado o mundo de forma humana, essa comunidade aparece sob a forma da alienação*. Pois seu sujeito, o homem, é um ser alienado* de si mesmo. Os homens, não em uma abstração, mas como indivíduos efetivos, vivos, particulares, são esse ser. Portanto, assim como eles são, assim ele próprio é. São, então, proposições idênticas dizer que o homem é alienado* de si mesmo e dizer que a sociedade desse homem alienado* é a caricatura de sua comunidade efetiva, de sua verdadeira vida genérica, dizer que, portanto, sua atividade aparece como tormento, sua própria criação como um poder alheio, sua riqueza como pobreza, seu laço essencial que o liga aos outros homens aparece como um laço inessencial e irrelevante, e a separação dos outros homens aparece antes como sua verdadeira existência, que sua vida aparece como sacrifício de sua vida, a realização de sua essência como desrealização de sua vida, sua produção como a produção de seu nada, seu poder sobre o objeto como o poder do objeto sobre ele, que ele, o senhor de sua criação, aparece como o servo dessa criação.

Ora, a Economia Política concebe a comunidade dos homens, ou a sua essência

5 Segue-se aqui a versão da MEGA, onde consta Gattungsgenuß (fruição genérica), e não Gattungsgeist (espírito genérico), como na MEW. (N.T.)

6 Marx joga com a composição da palavra Gemeinwesen (gemein = comum; Wesen = ser, essência), traduzida como comunidade. (N.T.). 
humana que ativa a si mesma, seu complemento mútuo com a vida do gênero, com a verdadeira vida humana, sob a forma da troca e do comércio. A sociedade, diz Destutt de Tracy, é uma série de trocas mútuas. Ela é esse movimento mesmo de integração mútua. A sociedade, diz Adam Smith, é uma sociedade comercial. Cada um de seus membros é um comerciante.

Vê-se como a Economia Política fixa a forma alienada* do tráfego social como a forma essencial, originária e correspondente à determinação humana.

A Economia Política - como o movimento efetivo - parte da relação do homem com o homem como a relação do proprietário privado com o proprietário privado. Quando se pressupõe o homem como proprietário privado, isto é, como possuidor exclusivo que, mediante essa posse exclusiva, dá provas de sua personalidade e se distingue do outro homem no modo como se relaciona com ela - a propriedade privada é sua existência pessoal, distintiva, portanto sua existência essencial -, então a perda ou a renúncia à propriedade privada é uma alienação do homem, assim como da propriedade privada mesma. Detenhamo-nos aqui apenas na última determinação. Se abandono minha propriedade privada a um outro, então ela deixa de ser minha; ela se torna uma coisa independente de mim, situada fora de meu domínio, uma coisa externa a mim. Alieno, portanto, minha propriedade privada. Em relação a mim, eu a ponho então como propriedade privada alienada. Mas somente a ponho em geral como coisa alienada, apenas suprimo (aufheben) minha relação pessoal com ela, devolvo-a aos poderes naturais elementares, se eu a alieno apenas em relação a mim. Ela só se torna propriedade privada alienada quando ao mesmo tempo deixa de ser minha propriedade privada, sem deixar por isso de ser propriedade privada em geral, ou seja, então, quando ela entra com um outro homem além de mim na mesma relação na qual ela estava para comigo mesmo, em uma palavra, quando ela se torna a propriedade privada de um outro homem. Excetuando-se o caso da violência - o que me leva a alienar minha propriedade privada a outro homem? A Economia Política responde corretamente: devido à necessidade, devido à carência. O outro homem também é proprietário privado, mas de uma outra coisa da qual eu tenho necessidade e da qual eu não posso ou não quero prescindir, que me parece uma carência para o aperfeiçoamento de minha existência e para a realização de minha essência.

O laço que estabelece a ligação de ambos os proprietários privados é a natureza específica do objeto que é a matéria de sua propriedade privada. 0 anseio por estes dois objetos, isto é, a carência deles, se mostra a cada um dos proprietários privados, the traz à consciência que ele, além da propriedade privada, tem ainda uma outra relação essencial com os objetos, que ele não é o ser particular pelo qual ele se toma, mas sim um ser total cujas carências estão na relação da propriedade interna - pois a carência de uma coisa é a prova mais evidente e irrefutável de 
que a coisa pertence à minha essência, que seu ser é para mim, sua propriedade é a propriedade, a peculiaridade de minha essência - com tudo, inclusive com as produções do trabalho dos outros. Ambos os proprietários são impelidos a renunciar à sua propriedade privada, mas a renunciar de tal modo que eles ao mesmo tempo confirmam a propriedade privada, ou a renunciar à propriedade privada no interior da relação da propriedade privada. Cada um aliena, então, uma parte de sua propriedade privada ao outro.

O relacionamento (Beziehung) social ou a relação (Verhältnis) social dos dois proprietários privados é então a reciprocidade da alienação, a relação da alienação posta em ambos os lados, ou a alienação como a relação dos dois proprietários, enquanto na propriedade privada simples a alienação só tem ainda lugar unilateralmente, na relação consigo.

A troca ou o escambo é, então, o ato social, o ato genérico, a comunidade, a integração e tráfego social dos homens no interior da propriedade privada e, assim, o ato genérico exterior, o ato genérico alienado. Exatamente por isso ela aparece como escambo. É, por isso, exatamente o contrário da relação social.

Mediante a alienação recíproca [durch die wechselseitige Entäußerung oder Entfremdung] da propriedade privada, a propriedade privada cai ela mesma na determinação da propriedade privada alienada. Pois, em primeiro lugar, ela deixou de ser o produto do trabalho, a personalidade exclusiva e distintiva de seu possuidor, pois este a alienou, ela escapou do possuidor de quem ela era um produto e adquiriu um significado pessoal para aquele cujo produto ela não é. Ela perdeu seu significado pessoal para o possuidor. Em segundo lugar, ela se relacionou com uma outra propriedade privada, foi equiparada a ela. Em seu lugar, entrou uma propriedade privada de outra natureza, assim como ela mesma substitui o lugar de uma propriedade privada de outra natureza. Em ambos os lados aparece, então, a propriedade privada como representante de uma propriedade privada de outra natureza, como o igual de um produto de outra natureza, e ambos os lados se relacionam um com outro de tal modo que cada um representa a existência de seu outro e ambos se relacionam um com outro mutuamente como substitutos de si mesmo e de seu outro. A existência da propriedade privada enquanto tal se tornou, portanto, um sucedâneo, um equivalente. Do lado de sua unidade imediata consigo mesma, ele só é ainda enquanto relação para com um outro. Enquanto equivalente, sua existência não é mais a que lhe é própria. Ela se tornou valor e, de modo imediato, valor de troca. Sua existência enquanto valor é uma existência distinta de sua existência imediata, exterior à sua essência específica, uma determinação alienada de si própria, apenas uma existência relativa dela.

Como se determina de maneira mais próxima esse valor, é algo a se desenvolver em outro lugar, bem como o modo como ele se torna preço. 
Pressuposta a relação da troca, o trabalho se torna trabalho remunerado imediato. Essa relação do trabalho alienado* alcança sua altura apenas mediante o fato de que 1) do lado do trabalho remunerado, o produto do trabalhador não está numa relação imediata com sua carência e sua determinação laboral, mas é determinada na direção de ambos os lados mediante combinações sociais alheias ao trabalhador; 2) aquele que compra o produto não o produz ele mesmo, mas troca o produzido por um outro. Naquela figura crua da propriedade privada alienada, do escambo, cada um dos dois proprietários privados produziu aquilo para o que lhe impeliram de imediato sua carência, sua predisposição e o material natural disponível. Cada um troca com outro, então, apenas o excedente de sua produção. 0 trabalho foi, sem dúvida, sua fonte de subsistência imediata, mas também ao mesmo tempo a confirmação de sua existência individual. Mediante a troca, seu trabalho se tornou parcialmente fonte de meios de aquisição. Sua finalidade e sua existência se tornaram distintas. 0 produto, enquanto valor, enquanto valor de troca, enquanto equivalente, não é mais produzido em razão de sua relação imediata pessoal com o produtor. Quanto mais multilateral se torna a produção, mais multilaterais, então, por um lado, se tornam as carências, mais unilaterais, por outro lado, se tornam as realizações dos produtores, e tanto mais o seu trabalho cai na categoria do trabalho remunerado, até que, por fim, ele se torna apenas esse significado e se torna completamente acidental e inessencial, tanto se o produtor está na relação da fruição imediata e da carência pessoal para com seu produto, quanto se a atividade, a ação do trabalho mesmo, é para ele a autofruição de sua personalidade, a realização de suas predisposições naturais e finalidades espirituais.

No trabalho remunerado reside: 1) a alienação* e a contingência do trabalho em relação ao sujeito trabalhador; 2) a alienação* e a contingência do trabalho em relação a seu objeto; 3) a determinação do trabalhador pelas carências sociais que, todavia, são para ele alheias e uma coerção à qual se submete por carências egoístas, por necessidade, e que tem para ele apenas o significado de uma fonte de satisfação para suas necessidades, assim como ele só existe para elas como um escravo das carências delas; 4) que a conservação de sua existência individual aparece ao trabalhador como finalidade de sua atividade, e seu fazer efetivo só conta para ele como meio; que ele toca sua vida para adquirir meios de subsistência.

Quanto maior, quanto mais formado, portanto, aparece o poder social no interior da relação de propriedade privada, tanto mais egoísta, associal e alienado* de sua própria essência se torna o homem.

Assim como a troca mútua dos produtos da atividade humana aparece como escambo, como barganha, do mesmo modo a troca e o complemento mútuo da atividade mesma aparecem como: divisão do trabalho, que faz do homem um ser o mais abstrato possível, um torno mecânico etc., e o transforma em uma criatura 
física e espiritualmente deformada.

Exatamente a unidade do trabalho humano é então considerada como divisão, porque o ser social só vêm à existência como seu contrário, na forma da alienação*. Com a civilização se intensifica a divisão do trabalho.

Sob o pressuposto da divisão do trabalho, o produto, o material da propriedade privada, adquire para o indivíduo cada vez mais o significado de um equivalente, e como ele não troca mais o seu excedente, mas o objeto de sua produção pode ser simplesmente indiferente para ele, então ele também não troca mais seu produto imediatamente por algo de que ele carece. 0 equivalente adquire sua existência como equivalente no dinheiro, que é agora o resultado imediato do trabalho remunerado e o mediador da troca. (Ver acima.)

No dinheiro, a indiferença completa tanto em face da natureza do material, em face da natureza específica da propriedade privada, como em face da personalidade do proprietário privado, apareceu a dominação completa da coisa alienada* sobre o homem. Aquilo que [contava] como a dominação da pessoa sobre a pessoa é agora a dominação universal da coisa sobre a pessoa, do produto sobre o produtor. Assim como a determinação da alienação da propriedade privada já residia no equivalente, no valor, do mesmo modo o dinheiro é a existência sensível e mesmo objetiva dessa alienação.

É compreensível que a Economia Política só possa conceber todo esse desenvolvimento como um factum, como o resultado malogrado de uma carência contingente.

A separação do trabalho de si mesmo = separação entre trabalhador e capitalista = separação de trabalho e capital, cuja forma originária se decompõe em propriedade fundiária e propriedade móvel ${ }^{7}$... A determinação originária da propriedade privada é o monopólio; assim que existe, então, uma constituição política, ela é a do monopólio. O monopólio aperfeiçoado é a concorrência. - Para o economista político, dividem-se produção, consumo e, como mediador de ambos, a troca ou a distribuição. A separação de produção e consumo, de atividade e fruição em indivíduos distintos e no mesmo indivíduo, é a separação do trabalho de seu objeto e de si mesmo como uma fruição. ${ }^{8} \mathrm{~A}$ distribuição é poder, que se põe em operação, da propriedade privada. - A separação mútua de trabalho, capital, propriedade fundiária, assim como a separação entre trabalho e trabalho, capital e capital, propriedade fundiária e propriedade fundiária, por fim, a separação entre trabalho e salário, capital e lucro, lucro e juros, finalmente, entre propriedade fundiária e renda fundiária, faz que a autoalienação* apareça tanto na figura da

7 No manuscrito, a palavra "móvel" não se encontra destacada. (N.E.A.).

8 Novamente, segue-se a MEGA na transcrição de Genuß no lugar de Geist, como consta na MEW. Cf. nota de rodapé n.5, acima. (N.T.). 
autoalienação* quanto da alienação* mútua.

Aqui ${ }^{9}$ Mill analisa, com a sua clareza e agudeza cínica habitual, a troca na base da propriedade particular.

O homem - este é o pressuposto fundamental da propriedade particular produz apenas para ter. A finalidade da produção é o ter. E a produção não somente tem uma tal finalidade útil, ela tem uma finalidade egoísta. 0 homem produz apenas para ter para si. 0 objeto de sua produção é a objetificação de sua necessidade egoísta imediata. O homem, para si - na condição selvagem, bárbara -, tem, por isso, a medida de sua produção na dimensão de sua necessidade imediata, cujo conteúdo é imediatamente o objeto produzido mesmo.

Por isso, nessa condição, o homem produz não mais do que ele necessita imediatamente. O limite de sua necessidade é o limite de sua produção. Demanda e oferta correspondem uma à outra, então, exatamente. A sua produção é medida por sua necessidade. Nesse caso não acontece nenhuma troca, ou a troca se reduz à troca de seu trabalho pelo produto de seu trabalho, e esta troca é a forma latente, germe $^{10}$ da troca efetiva. Assim que ocorre a troca, ocorre a produção excedente para além dos limites imediatos da posse. Porém, essa produção excedente não é uma elevação acima da carência egoísta. Ela é antes apenas uma maneira mediada de satisfazer uma carência que não encontra sua objetificação imediatamente nessa produção, mas sim na produção de um outro. A produção se tornou fonte de meios de aquisição, trabalho remunerado. Enquanto na primeira relação, portanto, a carência é a medida da produção, na $2^{a}$ relação é a produção, ou antes a posse do produto a medida do quanto as carências podem se satisfazer.

Eu produzi para mim e não para ti, assim como tu produzistes para ti e não para mim. O resultado da minha produção tem, em si para si, tão pouca relação contigo quanto o resultado da tua produção tem uma relação imediata comigo. Isto é, nossa produção não é11 produção do homem para o homem enquanto homem, isto é, não é produção social. Enquanto homens, nenhum de nós tem, então, uma relação de fruição para com o produto dos outros. Enquanto homens, não existimos para nossas produções mútuas. Nossa troca também não pode, por isso, ser o movimento de mediação no qual se confirma que o meu produto é para ti, uma vez que é uma objetificação tua própria essência, de tuas carências. Pois o laço de nossas produções uma para a outra não é a essência humana. A troca pode apenas pôr em movimento, apenas confirmar o caráter que cada um de nós tem para com seu próprio produto, portanto para com a produção do outro. Cada um de nós vê em seu produto apenas

\footnotetext{
9 Seguindo a edição da coleção Studienbibliothek da editora Suhrkamp, omitem-se na presente tradução os trechos transcritos por Marx do livro de Mill (N.T.).

10 No manuscrito, "germe" consta acima de "forma". (N.E.A.).

11 No manuscrito consta "são". (N.E.A.).
} 
seu próprio interesse pessoal objetificado, e no produto dos outros, portanto, um outro interesse pessoal dele independente, alheio e objetivo.

Tu tens como homem certamente uma relação humana para com o meu produto: tu tens a carência do meu produto. Ele existe então para ti como objeto de teu desejo e de tua vontade. Mas tua carência, teu desejo, tua vontade são carência, desejo e vontade impotentes para meu produto. Isso significa, então, que tua essência humana, essência que, portanto, está necessariamente em uma relação interna para com minha produção, não é o teu poder, a tua propriedade nessa produção, pois não é a tua particularidade, não é o poder da essência humana o que é reconhecido em minha produção. Eles são antes o laço que te faz dependente de mim, pois te põem em uma dependência do meu produto. Longe de eles serem o meio que te daria poder sobre a minha produção, elas são antes o meio para me dar poder sobre você.

Se eu produzo mais do que eu mesmo posso precisar imediatamente do objeto produzido, então minha produção excedente é calculada, refinada pela tua carência. Apenas em aparência eu produzo um excedente desse objeto. Na verdade, produzo um outro objeto, o objeto de tua produção que eu tenho a intenção de trocar por esse excedente, uma troca que eu já executei no pensamento. A relação social em que eu estou para com você, meu trabalho para tua carência, é, por isso, também mera aparência, e nosso complemento mútuo é do mesmo modo mera aparência, à qual serve de base a pilhagem mútua. A intenção da pilhagem, da fraude, fica necessariamente escamoteada, pois ali nossa troca é uma troca egoísta, tanto do meu quanto do seu lado, porque cada interesse próprio busca sobrepujar o alheio, de modo que nós procuramos necessariamente nos enganar. A medida do poder sobre teu objeto que atribuo ao meu precisa, no entanto, para se tornar um poder efetivo, do teu reconhecimento. Nosso reconhecimento recíproco sobre o poder recíproco dos nossos objetos é, porém, uma luta, e na luta triunfa quem possui mais energia, força, inteligência e habilidade. Se a força física é suficiente, então te saqueio diretamente. Se o reino da força física é quebrado, então procuramos nos enganar mutuamente pelas aparências e o mais hábil ludibria o outro. Quem ludibria o outro, isso é, do ponto de vista do todo da relação, um acaso. O ludíbrio ideal, visado, acontece de ambos os lados, isto é, cada um dos dois ludibriou o outro em seu próprio juízo.

A troca é mediada, portanto, por ambos os lados, necessariamente através do objeto da produção recíproca e da posse recíproca. A relação ideal com os objetos recíprocos da nossa produção é, todavia, nossa carência recíproca. Mas a relação real, a relação que se põe na efetividade, a relação verdadeira, a relação que leva a si mesma a cabo, é apenas a posse recíproca e exclusiva da produção recíproca. 0 que dá à tua carência de minha coisa um valor, uma dignidade, um efeito para mim é apenas o teu objeto, o equivalente de meu objeto. Nosso produto mútuo 
é, portanto, o meio, a mediação, o instrumento, o poder reconhecido de nossas carências mútuas uma sobre a outra. Tua demanda e o equivalente de tuas posses são, então, sinônimos, termini igualmente válidos para mim, e tua demanda só tem um sentido, já que tem um efeito, quando tem um sentido e um efeito em relação a mim. Como mero homem, tua demanda é, sem esse instrumento, uma aspiração insatisfeita de tua parte, uma ocorrência inexistente para mim. Tu, enquanto homem, não está, portanto, em relação com meu objeto, pois eu mesmo não tenho uma relação humana com ele. Mas o meio é o verdadeiro poder sobre um objeto, e por isso nós contemplamos mutuamente nosso produto como o poder de cada um sobre o outro e sobre si mesmo, isto é, nosso próprio produto se levantou contra nós, ele parecia nossa propriedade, na verdade nós somos sua propriedade. Nós mesmos somos excluídos da verdadeira propriedade, pois nossa propriedade exclui os outros homens.

A única linguagem compreensível que falamos uns com os outros é a de nossos objetos em sua relação uns com os outros. Nós não compreenderíamos uma linguagem humana, ela restaria sem efeito. Ela seria percebida, sentida por um dos lados como pedido, como súplica e, portanto, como uma humilhação, e consequentemente seria expressa com vergonha, com o sentimento de ser algo descartável. Pelo outro lado, seria recebida e rechaçada como desaforo ou loucura. Estamos de tal modo alienados* mutuamente da essência humana que a linguagem imediata dessa essência nos aparece como uma violação da dignidade humana, e, pelo contrário, a linguagem alienada* dos valores materiais aparece como a dignidade humana justificada, autoconfiante e que reconhece a si mesma.

Com efeito: aos teus olhos o teu produto é um instrumento, um meio para se apoderar de meu produto e, assim, para a satisfação de tua necessidade. Mas aos meus olhos ele é a finalidade de nossa troca. Tu vales para mim antes como meio e instrumento para a produção desse objeto que é um fim para mim, assim como tu, ao contrário, vales nessa relação para com meu objeto. Mas 1) cada um de nós faz realmente isso no modo como o outro o contempla. Tu fizestes de ti mesmo realmente um meio, um instrumento, um produtor de teu próprio objeto, a fim de se apoderar do meu; 2 ) teu próprio objeto é para ti apenas o invólucro sensível, a figura oculta de meu objeto; pois tua produção significa, quer exprimir: a aquisição de meu objeto. Tu tornastes a ti mesmo, então, de fato, um meio, um instrumento de teu objeto, cujo escravo é teu desejo, e tu prestastes serviços de escravo para que o objeto nunca mais faça um favor a teu desejo. Quando, no começo do desenvolvimento, essa escravidão mútua do objeto através de nós aparece então também e de fato como a relação da dominação e da escravidão, isso é apenas a expressão bruta e franca de nossa relação essencial.

Nosso valor recíproco é para nós o valor de nossos objetos recíprocos. 0 
homem mesmo, então, é para nós reciprocamente sem valor.

Suponhamos que nós tivéssemos produzido enquanto homens: cada um de nós teria, em sua produção, afirmado duplamente a si mesmo a ao outro. Eu teria 1) objetificado minha individualidade e sua peculiaridade em minha produção e, assim, fruído tanto de uma manifestação vital individual durante a atividade como, na contemplação do objeto, da alegria individual de saber minha personalidade como um poder objetivo, sensivelmente contemplável e, por isso, elevado acima de toda dúvida. 2) Em tua fruição ou em teu uso de meu produto, eu teria imediatamente a fruição tanto da consciência de ter satisfeito em meu trabalho uma carência humana, isto é, de ter objetificado a essência humana e, assim, de ter proporcionado à carência de um outro ser humano seu objeto correspondente, 3) de ter sido para ti o mediador entre ti e o gênero, de ser sentido e sabido por ti mesmo como complemento de teu próprio ser e como uma parte necessária de ti mesmo, portanto, de me saber confirmado tanto em teu pensamento quanto em teu amor, 4) de ter produzido imediatamente em minha manifestação vital individual a tua manifestação vital, portanto de ter confirmado e efetivado imediatamente em minha atividade individual o meu ser, minha essência humana, minha comunidade.

Nossas produções seriam assim vários espelhos desde os quais nossa essência luziria em reflexo.

Nisso, essa relação se torna recíproca, sucederia de teu lado o que sucede do meu.

Observemos os distintos momentos como eles aparecem naquilo que supusemos:

Meu trabalho seria manifestação [Äußerung] vital livre, portanto fruição da vida. Sob o pressuposto da propriedade privada, ele é alienação [Entäußerung] vital, pois eu trabalho para viver, para me proporcionar um meio de vida. Meu trabalho não é vida.

Em segundo lugar: no trabalho, então, seria afirmada a particularidade de minha individualidade, pois minha vida individual se afirma. O trabalho seria, portanto, propriedade verdadeira, ativa. Sob o pressuposto da propriedade privada, minha individualidade está alienada a tal ponto que essa atividade me é detestável, um tormento e antes apenas a aparência de uma atividade, por isso apenas uma atividade forçada e que só me é imposta por uma carência contingente externa, não por uma carência necessária interna.

Meu trabalho só pode aparecer no meu objeto como aquilo que ele é. Ele não pode aparecer como aquilo que, segundo sua essência, ele não é. Por isso ele só aparece ainda como expressão objetiva, sensível, contemplada e, assim, elevada acima de qualquer dúvida, de minha perda de mim mesmo e de minha impotência. 
A tradução tomou como base a edição da MEW (Marx, K. (1968). „Auszüge aus James Mills Buch 'Élémens d'économie politique'”. In: Marx, K; Engels, F. Marx-EngelsWerke. Ergänzungsband I. Berlim: Dietz, pp.443-463), com consulta à edição incluída como anexo no volume dos Manuscritos na coleção Studienbibliothek da Suhrkamp, por sua vez extraída da MEGA, e que recebeu do editor Michael Quante o título "A concepção de reconhecimento" (Marx, K. (2009). “Das Konzept der Anerkennung”. In: Marx, K. Ökonomisch-philosophische Manuskripte. Kommentar von Michael Quante. Frankfurt a.M.: Suhrkamp, pp.188-208.).

Tradução de Luiz Philipe de Caux

Recebido em: 24.03.2015 Aceito em: 29.01.2016 